\title{
Effect of Heat Treatment on Microstructure and Mechanical Properties of 12Cr-10Ni-0.25Ti-0.7Mo Stainless Steel
}

\author{
S. Chenna Krishna $\cdot$ J. Srinath $\cdot$ Abhay K. Jha $\cdot$ \\ Bhanu Pant $\cdot$ S. C. Sharma $\cdot$ Koshy M. George
}

Received: 27 March 2013/Revised: 16 May 2013/Accepted: 21 May 2013/Published online: 19 June 2013

(C) Springer Science+Business Media New York and ASM International 2013

\begin{abstract}
In this investigation, a precipitation hardenable martensitic stainless steel (12Cr-10Ni-0.25Ti-0.7Mo) was subjected to different heat treatment cycles to study their influence on the microstructure and mechanical properties. The heat treatment cycles include solution treatment (S), cryogenic treatment (C), and aging (A). Two solution treatment temperatures, 750 and $1000{ }^{\circ} \mathrm{C}$, and two aging temperatures, 250 and $500{ }^{\circ} \mathrm{C}$, were selected. Solution treatment was followed by a cryogenic treatment at $-70{ }^{\circ} \mathrm{C}$ for $2 \mathrm{~h}$ and an aging treatment at the aforementioned temperatures. Transmission electron microscopy of the solution-treated samples showed four phases: martensite matrix, $\mathrm{M}_{23} \mathrm{C}_{6}$ carbide, $\mathrm{Ti}(\mathrm{C}, \mathrm{N})$, and retained austenite. On aging at $500{ }^{\circ} \mathrm{C}$, an additional phase $\left(\mathrm{Ni}_{3} \mathrm{Ti}\right.$ precipitates) was observed in the martensite matrix. Mechanical properties were evaluated at room temperature for all the heat-treated samples. A reasonable increase in yield strength (YS) was observed after cryogenic treatment possibly due to transformation of retained austenite to martensite. After aging at $500{ }^{\circ} \mathrm{C}$, a significant increase in the YS was observed over solution-treated condition. This increase in YS after aging is attributed to precipitation of fine $\mathrm{Ni}_{3} \mathrm{Ti}$ precipitates. Solution treatment temperature had an insignificant effect on the mechanical properties of the stainless steel.
\end{abstract}

S. Chenna Krishna $(\bowtie) \cdot$ J. Srinath · A. K. Jha · B. Pant .

S. C. Sharma

Materials and Metallurgy Group, Materials and Mechanical Entity, Vikram Sarabhai Space Centre, Trivandrum 695022 , India

e-mail: chenna.sk@gmail.com

K. M. George

Materials and Mechanical Entity, Vikram Sarabhai Space Centre, Trivandrum 695 022, India
Keywords Cryogenic treatment · Aging ·

Mechanical properties - Martensitic stainless steel

\section{Introduction}

Precipitation hardenable $(\mathrm{PH})$ stainless steels are widely used in the aerospace industry due to their high strength, weldability, good toughness, and adequate ductility. These steels are most commonly strengthened by the formation of fine intermetallics consisting of $\mathrm{Ni}, \mathrm{Ti}, \mathrm{Al}$, and $\mathrm{Mo}$ [1-4]. However, a few $\mathrm{PH}$ steels gain strength by the precipitation of a copper-rich phase, with copper as the major precipitating element. 17-4 PH stainless steel is one such high strength steel strengthened by copper precipitates [5-7]. The steel used in this study is $12 \mathrm{Cr}-10 \mathrm{Ni}$ martensitic stainless steel with minor additions of molybdenum and titanium. Molybdenum is added to improve the resistance to tempering [8]. Titanium plays a key role as a strengthening element by formation of $\mathrm{Ni}_{3} \mathrm{Ti}$ precipitates during aging treatment [1-4]. In addition to increasing strength, titanium also fixes the carbon and nitrogen by forming fine $\operatorname{Ti}(\mathrm{C}, \mathrm{N})$ [9-11]. This steel has an austenitic structure above $700{ }^{\circ} \mathrm{C}$ which transforms to martensite on air cooling [12]. Hence, solution treatment is performed at temperatures above $750{ }^{\circ} \mathrm{C}$ and preferably around $1000{ }^{\circ} \mathrm{C}$ to dissolve the carbides and other particles to attain a homogenous austenite structure. A small amount of retained austenite forms after the solution treatment along with martensite. Retained austenite is not desirable in most cases as it prevents the steel from attaining its maximum strength and induces instability in the materials performance due to the possibility of transformation during the service. Cryogenic treatment is widely employed for such steels to ensure that martensitic transformation is complete $[13,14]$. It was reported that the cryogenic treatment would 
also promote secondary carbide precipitation and provide other advantages, such as higher strength, increased wear resistance, and improved dimensional and microstructural stability, depending on the composition of the steel [15, 16]. The literature available on the effect of heat treatments on the mechanical properties of the current steel is limited. Therefore, an attempt was made to study the same with an aim to design the heat treatment to obtain the optimum properties.

\section{Experimental}

The material used in this study was produced through vacuum induction melting (VIM) and refined by vacuum arc remelting (VAR). The chemical composition of the steel is given in Table 1 . The cast ingot was converted to bars by forging in the temperature range of $1000-1080{ }^{\circ} \mathrm{C}$. These bars were hot rolled to realize a plate of $4 \mathrm{~mm}$ thick. Samples from this plate were subjected to different heat treatment cycles. They were solution-treated at two temperatures, 750 and $1000{ }^{\circ} \mathrm{C}$, for $0.5 \mathrm{~h}$ and were subsequently air cooled. These solution-treated samples were subjected to the cryogenic treatment at $-70{ }^{\circ} \mathrm{C}$ for $2 \mathrm{~h}$, after which they were left in air to return to room temperature. After the cryogenic treatment, the samples were aged at two different temperatures, 250 and $500{ }^{\circ} \mathrm{C}$, with a holding time of $2 \mathrm{~h}$, followed by air cooling. The heat treatment cycles employed in the study will be designated hereafter as $10 \mathrm{~S}$, 7S, 10SC, 7SC, 10SCA, 10SCLA, 7SCA, and 7SCLA, the details of which are given in Table 2. The heat-treated specimens were characterized for microstructure and mechanical properties.

Light microscopy of the samples was performed by conventional polishing techniques using different grades of emery papers, alumina paste, and diamond paste. The polished samples were etched with $10 \mathrm{~mL} \mathrm{HNO}_{3}+10 \mathrm{~mL}$ acetic acid $+15 \mathrm{~mL} \mathrm{HCl}+2-5$ drops glycerin. Hardness measurements were made with a Rockwell hardness tester using a major load of $150 \mathrm{~kg}$. An average of six readings was taken for reporting the hardness for a particular heattreated condition. Tensile properties of the steel were evaluated at room temperature as per ASTM E8M. All the specimens for tensile testing were fabricated after the heat treatment. Tests were conducted at a strain rate of $10^{-3} \mathrm{~s}^{-1}$ using a universal testing machine.
Thin foils for TEM were prepared by cutting 300- $\mu$ mthick slices from the samples using a low speed saw; slices were further reduced to about $100 \mu \mathrm{m}$ by polishing both sides of the foil using $\mathrm{SiC}$ emery paper. Disks of $3 \mathrm{~mm}$ diameter were punched from these thin foils. One side of the $3 \mathrm{~mm}$ disk was dimpled, followed by ion milling with an incident beam angle of $4^{\circ}$. The thin foils were examined with a transmission electron microscope (TEM) equipped with energy dispersive $x$-ray spectroscopy (EDS) operated at $200 \mathrm{kV}$.

\section{Results and Discussion}

\section{Microstructure}

The microstructure of the solution-treated steel at 750 and $1000{ }^{\circ} \mathrm{C}$ consists of martensite and retained austenite with some carbides, as shown in Fig. 1. The carbon content in the present steel was very low $(0.018 \mathrm{wt} \%)$, so the martensite observed was lath martensite. The typical microstructure of $7 \mathrm{~S}$ and $10 \mathrm{~S}$ samples is shown in Fig. 1(a and b), respectively. The martensite laths were fine in the case of $7 \mathrm{~S}$ samples, and the width of laths increased with increase in temperature. It was suggested in the literature that austenite grains coarsen in the temperature range of $1000-1050{ }^{\circ} \mathrm{C}[8,10,13,14]$. Strong carbide formers, such as $\mathrm{Cr}, \mathrm{Ti}$, and $\mathrm{Nb}$, inhibit the austenite grain growth below $1000{ }^{\circ} \mathrm{C}$ by pinning the grain boundaries. On the contrary, austenite grains grow remarkably at and above $1000{ }^{\circ} \mathrm{C}$ which in turn results in growth of martensite laths. This growth occurs due to the dissolution of the carbides at and above $1000{ }^{\circ} \mathrm{C}$. It is evident from Fig. 1 that the volume fraction of carbides is higher for $7 \mathrm{~S}$ and with the increase of temperature to $1000{ }^{\circ} \mathrm{C}$, the dissolution of carbides occurred as shown in Fig. 1(b).

Table 2 Details of heat treatment cycles employed in the study

\begin{tabular}{ll}
\hline Designation & Heating cycle \\
\hline 7S-solution treatment & $750{ }^{\circ} \mathrm{C} / 0.5 \mathrm{~h} /$ air cooling (AC) \\
10S-solution treatment & $1000{ }^{\circ} \mathrm{C} / 0.5 \mathrm{~h} / \mathrm{AC}$ \\
C-cryo treatment & $-70{ }^{\circ} \mathrm{C} / 2 \mathrm{~h} / \mathrm{AC}$ \\
LA-low temperature aging & $250{ }^{\circ} \mathrm{C} / 2 \mathrm{~h} / \mathrm{AC}$ \\
A-peak aging & $500{ }^{\circ} \mathrm{C} / 2 \mathrm{~h} / \mathrm{AC}$ \\
\hline
\end{tabular}

Table 1 Chemical composition of the steel in wt $\%$

\begin{tabular}{llllllllllllll}
\hline Element & $\mathrm{C}$ & $\mathrm{Cr}$ & $\mathrm{Ni}$ & $\mathrm{Mo}$ & $\mathrm{Ti}$ & $\mathrm{S}$ & $\mathrm{P}$ & $\mathrm{Si}$ & $\mathrm{Mn}$ & $\mathrm{Al}$ & $\mathrm{N}$ \\
\hline$\%$ & 0.018 & 12.2 & 9.8 & 0.72 & 0.23 & 0.003 & 0.005 & 0.07 & 0.03 & 0.04 & 0.006 & $\mathrm{Bal}$ \\
\hline
\end{tabular}




\section{Hardness}

The hardness of steel at different aging temperature and time is plotted in Fig. 2. It can be seen that both isochronal and isothermal aging curves show a peak in hardness, after which the hardness decreased. This peak hardness may be caused by the formation of fine precipitates distributed uniformly throughout the matrix; the decrease in hardness after the peak is primarily due to over-aging, i.e., coarsening of the precipitates resulting in higher inter-precipitate spacing. At still higher temperatures, dissolution of the strengthening precipitates is responsible for the reduction in hardness.

The variation of hardness with aging temperature is shown in Fig. 2(a). The high hardness on aging in the temperature range of $450-500{ }^{\circ} \mathrm{C}$ may be due to the precipitation of nano-sized intermetallics in the martensite matrix. Hardness of the steel has increased by nearly $28 \%$ after aging at $500{ }^{\circ} \mathrm{C}$ for $1 \mathrm{~h}$. Figure 2(b) shows the effect of aging time on the hardness of the steel at $500{ }^{\circ} \mathrm{C}$. The hardness increased from $28 \mathrm{HRC}$ in the solution-treated condition to $42 \mathrm{HRC}$ after aging at $500{ }^{\circ} \mathrm{C}$ for $2 \mathrm{~h}$, after which a drop in hardness was observed. A $33 \%$ increase in hardness was noticed after peak aging at $500{ }^{\circ} \mathrm{C}$ for $2 \mathrm{~h}$.

\section{Tensile Strength}

The variation in ultimate tensile strength (UTS) of the steel with each step of the heat treatment for both $7 \mathrm{~S}$ and $10 \mathrm{~S}$ conditions is illustrated in Fig. 3. It was observed that $10 \mathrm{~S}$ showed higher UTS than that of $7 \mathrm{~S}$ for all the conditions. The typical values obtained were in the range of 900-1,048 and $929-1,066 \mathrm{MPa}$ for $7 \mathrm{~S}$ and $10 \mathrm{~S}$, respectively. The average UTS of SC and SCLA were similar to that of the "S" samples for both solution treatment temperatures.
Jaswin and Mohanlal [15] reported that no significant change was noticed in UTS for EN52 and 21-4N valve steel after cryogenic treatment and tempering/aging.

On the contrary, SCA showed a sharp increase in UTS for both $10 \mathrm{~S}$ and $7 \mathrm{~S}$ conditions. An increase of 14.7 and $16.4 \%$ in the UTS was observed for $10 \mathrm{~S}$ and $7 \mathrm{~S}$ samples, respectively, after peak aging. This increase in strength may be attributed to the formation of very fine intermetallic of $\mathrm{Ni}$ and $\mathrm{Ti}\left(\mathrm{Ni}_{3} \mathrm{Ti}\right)$ during aging treatment [1-4].

The variation in yield strength (YS) after heat treatment for both $10 \mathrm{~S}$ and $7 \mathrm{~S}$ samples is shown in Fig. 4. The difference in the YS between $7 \mathrm{~S}$ and $10 \mathrm{~S}$ conditions after $\mathrm{S}$, SCLA, and SCA treatments was observed to be minimal, at less than $20 \mathrm{MPa}$. However, after the cryogenic treatment, the difference in YS for $7 \mathrm{~S}$ and $10 \mathrm{~S}$ samples was $40 \mathrm{MPa}$, with $10 \mathrm{~S}$ showing a higher value. The YS has increased by 109 and $62 \mathrm{MPa}$ for $10 \mathrm{~S}$ and $7 \mathrm{~S}$ samples, respectively, after cryogenic treatment. The increase in YS after the cryogenic treatment may be attributed to the transformation of retained austenite to martensite at cryogenic temperatures. This steel exhibits a $M_{\mathrm{S}}$ (martensite start) temperature considerably below the room temperature and hence, complete transformation will occur only after the cryogenic treatment at -70 to $-80{ }^{\circ} \mathrm{C}$. The difference in YS for $7 \mathrm{~S}$ and $10 \mathrm{~S}$ after cryogenic treatment is primarily due to the difference in solution treatment temperature. For higher solution treatment temperature, there is more retained austenite and more carbide dissolution in the matrix. The carbide dissolution for 10S sample can be clearly seen in Fig. 1(b) with very few carbide particles. As the carbon content increases, the $M_{\mathrm{s}}$ temperature of the steel decreases, retaining the higher amount of austenite during quenching $[13,14]$. This also results in harder martensite after transformation of retained austenite by cryogenic treatment. On the contrary, a lower solution treatment
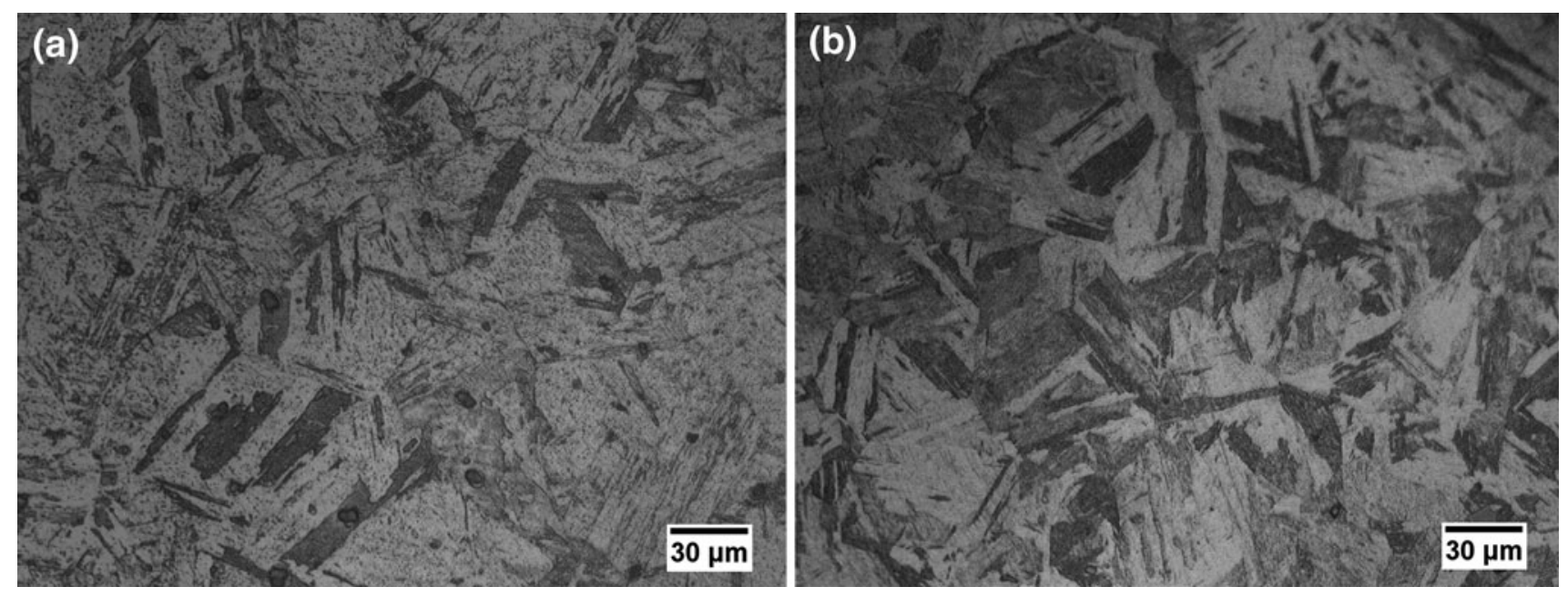

Fig. 1 Microstructure of the $12 \mathrm{Cr}-10 \mathrm{Ni}-0.25 \mathrm{Ti}-0.7 \mathrm{Mo}$ steel after solution treatment at two temperatures (a) $750{ }^{\circ} \mathrm{C},(\mathbf{b}) 1000{ }^{\circ} \mathrm{C}$ 
(a)

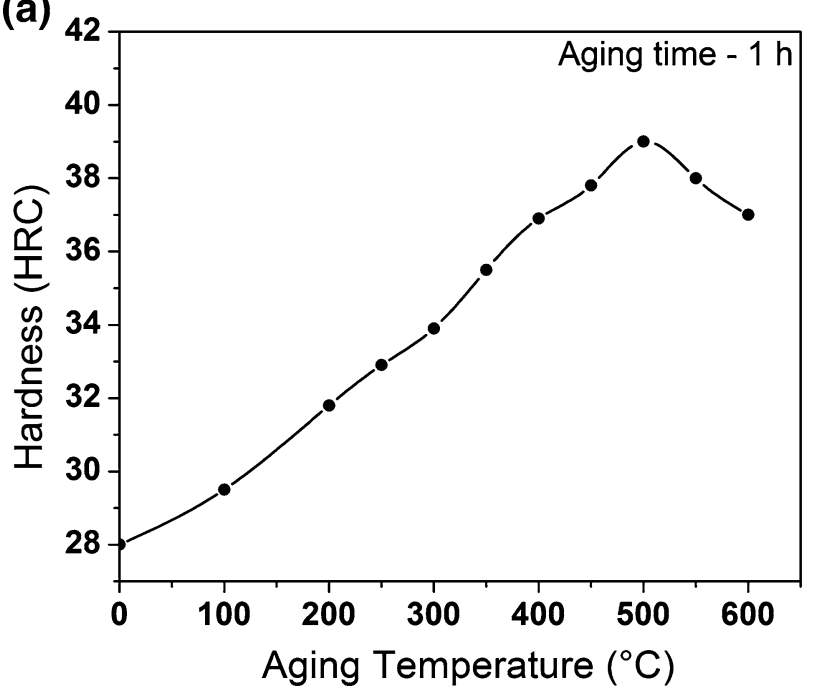

(b)

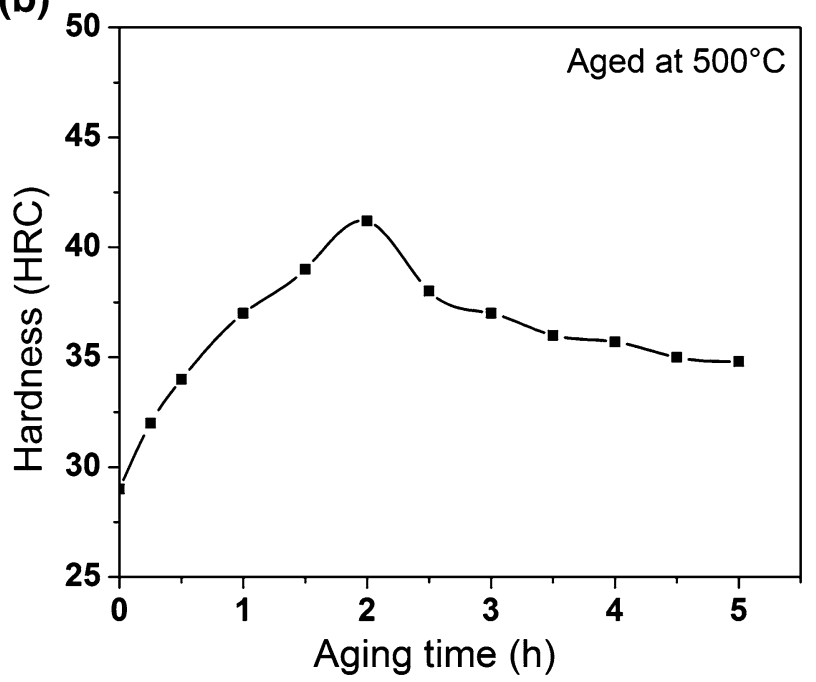

Fig. 2 Effect of aging time and temperature on the hardness of $12 \mathrm{Cr}-10 \mathrm{Ni}-0.25 \mathrm{Ti}-0.7 \mathrm{Mo}$ steel (a) aging temperature, (b) aging time

temperature will result in a lower content of retained austenite with a higher volume fraction of carbides, as evident from Fig. 1(a). This lower content of retained austenite, which subsequently transforms to martensite, was responsible for the lower increase in YS after cryo treatment for solution-treated samples at $750{ }^{\circ} \mathrm{C}(62 \mathrm{MPa})$ compared to 10S (109 MPa) samples.

An increase of 166 and $186 \mathrm{MPa}$ in YS was observed after low temperature aging for $7 \mathrm{~S}$ and $10 \mathrm{~S}$ conditions, respectively. This can be considered as an under aged condition, where precipitate nucleation begins and only few precipitates will grow in size, sufficient to strengthen the alloy. However, the peak strength is observed after aging at $500{ }^{\circ} \mathrm{C}$ where, an increase of 414 and $439 \mathrm{MPa}$ in YS was observed for $7 \mathrm{~S}$ and $10 \mathrm{~S}$ conditions, respectively.

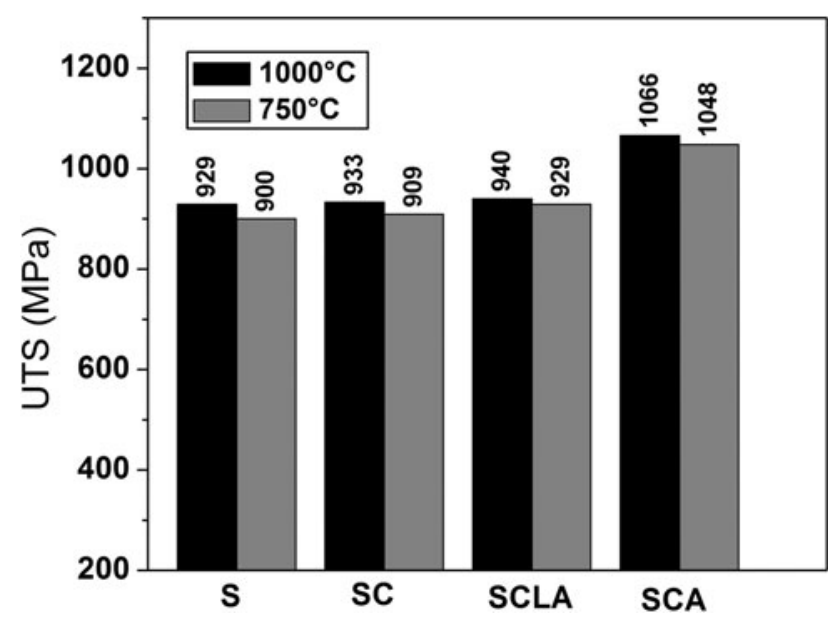

Fig. 3 Effect of different heat treatment on the ultimate tensile strength of the $12 \mathrm{Cr}-10 \mathrm{Ni}-0.25 \mathrm{Ti}-0.7 \mathrm{Mo}$ steel

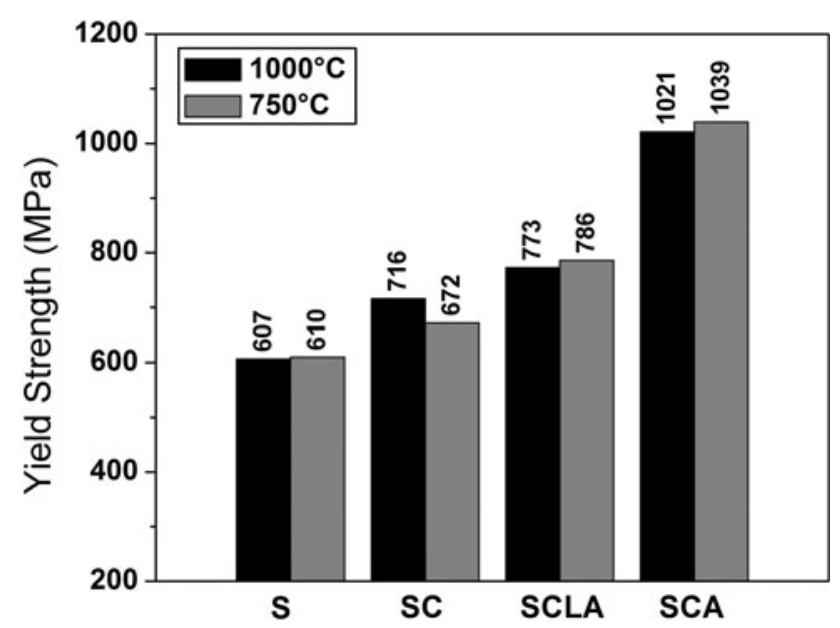

Fig. 4 Effect of different heat treatment on the yield strength of the $12 \mathrm{Cr}-10 \mathrm{Ni}-0.25 \mathrm{Ti}-0.7 \mathrm{Mo}$ steel

This increase in YS is attributed to the formation of very fine $\mathrm{Ni}_{3} \mathrm{Ti}$ precipitates.

\section{Elongation}

Figure 5 shows the variation in ductility of the steel after different heat treatment for a solution-treated sample at 750 and $1000{ }^{\circ} \mathrm{C}$. The difference in the ductility of $7 \mathrm{~S}$ and $10 \mathrm{~S}$ was observed to be small for all the heat-treated conditions. After the sub-zero treatment, a ductility of 15.2 and $16.2 \%$ was observed for $10 \mathrm{~S}$ and $7 \mathrm{~S}$ conditions, respectively. A good ductility was retained after aging at 250 and $500{ }^{\circ} \mathrm{C}$. This is quite interesting, considering the fact that good strength and ductility were obtained after aging. A ductility of 15.6 and $14.9 \%$ were observed for $10 \mathrm{~S}$ and $7 \mathrm{~S}$ conditions, respectively, after aging at $500{ }^{\circ} \mathrm{C}$. 


\section{Transmission Electron Microscopy (TEM)}

The transmission electron micrographs of the solutiontreated specimen are shown in Fig. 6. The bright-field (BF) image consists of typical lath martensite containing a high density of dislocations and retained austenite as shown in Fig. 6(a). The corresponding dark-field (DF) image is shown in Fig. 6(b) with retained austenite appearing bright. It can be seen that retained austenite is located between martensite lath. A blocky type of retained austenite is

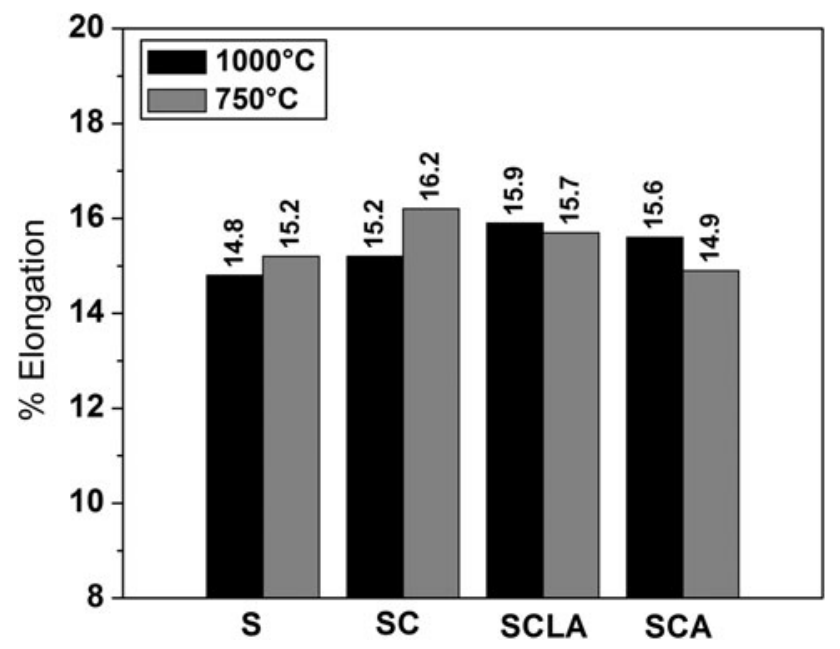

Fig. 5 Effect of different heat treatment on the ductility of the $12 \mathrm{Cr}-10 \mathrm{Ni}-0.25 \mathrm{Ti}-0.7 \mathrm{Mo}$ steel

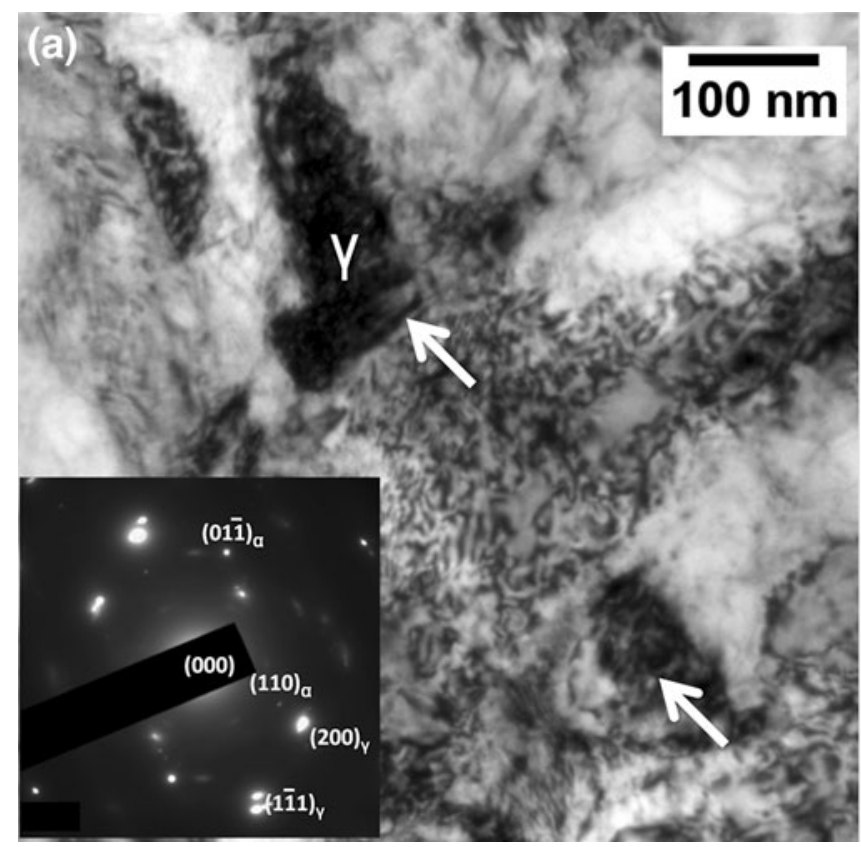

Fig. 6 Transmission electron micrograph of the solution-treated specimen at $750{ }^{\circ} \mathrm{C}$ for $0.5 \mathrm{~h}$ followed by air cooling, martensite with retained austenite: (a) bright-field image of retained austenite observed, as shown in Fig. 6(a, b). The selected area diffraction pattern (SAD) inserted in Fig. 6(a) shows the spot pattern corresponding to austenite $(\gamma)$ and martensite $(\alpha)$.

The BF micrograph of the solution-treated specimen, showing coarse, cube-shaped particles in the martensite matrix, is shown in Fig. 7(a). The EDS spectrum obtained from this particle is shown in Fig. 7(b). The spectrum shows the prominent peaks of $\mathrm{Ti}$ and $\mathrm{N}$ indicating that the particle is primarily $\operatorname{Ti}(\mathrm{C}, \mathrm{N})$. The average size of the cubeshaped carbide in Fig. 7(a) was measured as $80-120 \mathrm{~nm}$. The BF image, and corresponding EDS spectrum, of the irregularly shaped particle in the solution-treated sample is shown in Fig. 8(a and b), respectively. The BF image shows the irregularly shaped particle in addition to cubeshaped particle in martensite matrix. In $\mathrm{Fe}-\mathrm{C}-\mathrm{Ni}-\mathrm{Cr}-\mathrm{Mo}$ system, the carbide $\mathrm{M}_{23} \mathrm{C}_{6}$ occurs as $(\mathrm{Fe}, \mathrm{Cr}, \mathrm{Mo}){ }_{23} \mathrm{C}_{6}$ with an FCC crystal structure with a lattice parameter of $1.062 \mathrm{~nm}[17,18]$. The EDS spectrum obtained from the irregularly shaped particle shows prominent peaks of $\mathrm{Cr}$, and $\mathrm{Fe}$ in addition to peaks of $\mathrm{C}$ and Mo. This spectrum indicates that the carbide is $\mathrm{M}_{23} \mathrm{C}_{6}$ type with chemical formula $(\mathrm{Fe}, \mathrm{Cr}, \mathrm{Mo})_{23} \mathrm{C}_{6}$ as reported in literature [17].

The TEM micrographs of the steel aged at $500{ }^{\circ} \mathrm{C}$ for $2 \mathrm{~h}$ are shown in Fig. 9. The BF image of the sample with precipitate distribution in the matrix is shown in Fig. 9(a). The precipitates are very fine, with sizes in the range of 2-4 nm. The DF image of the precipitates and corresponding SAD pattern are shown in Fig. 9(b and c), respectively. The SAD pattern was analyzed to identify the

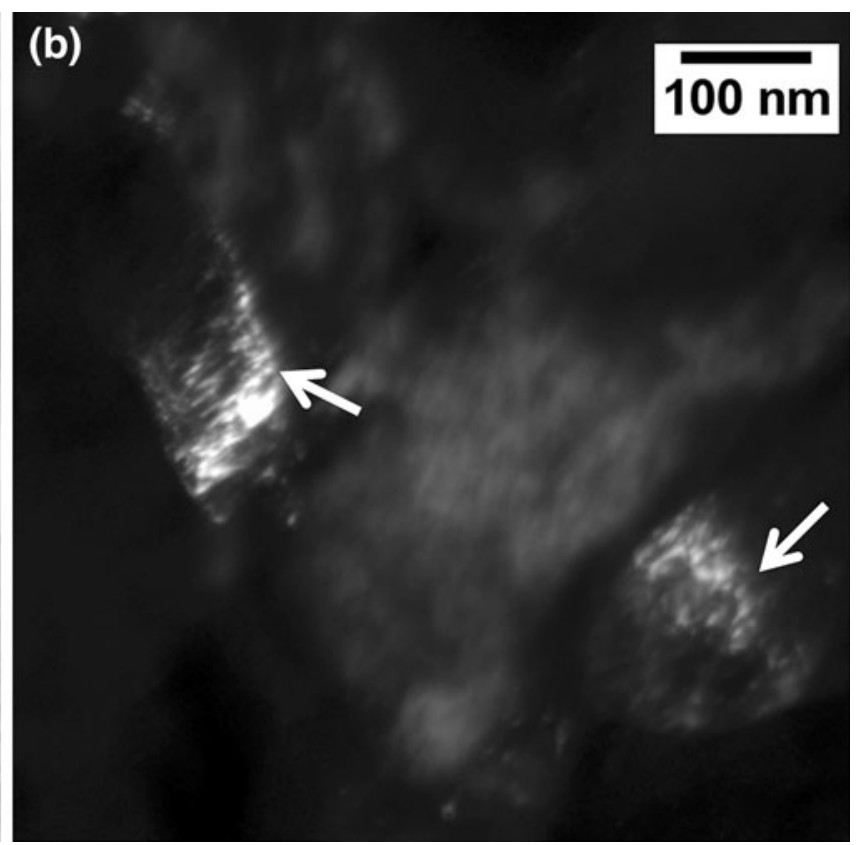

and selected area diffraction pattern. (b) Dark-field image of retained austenite obtained using $\gamma$ diffraction spot 

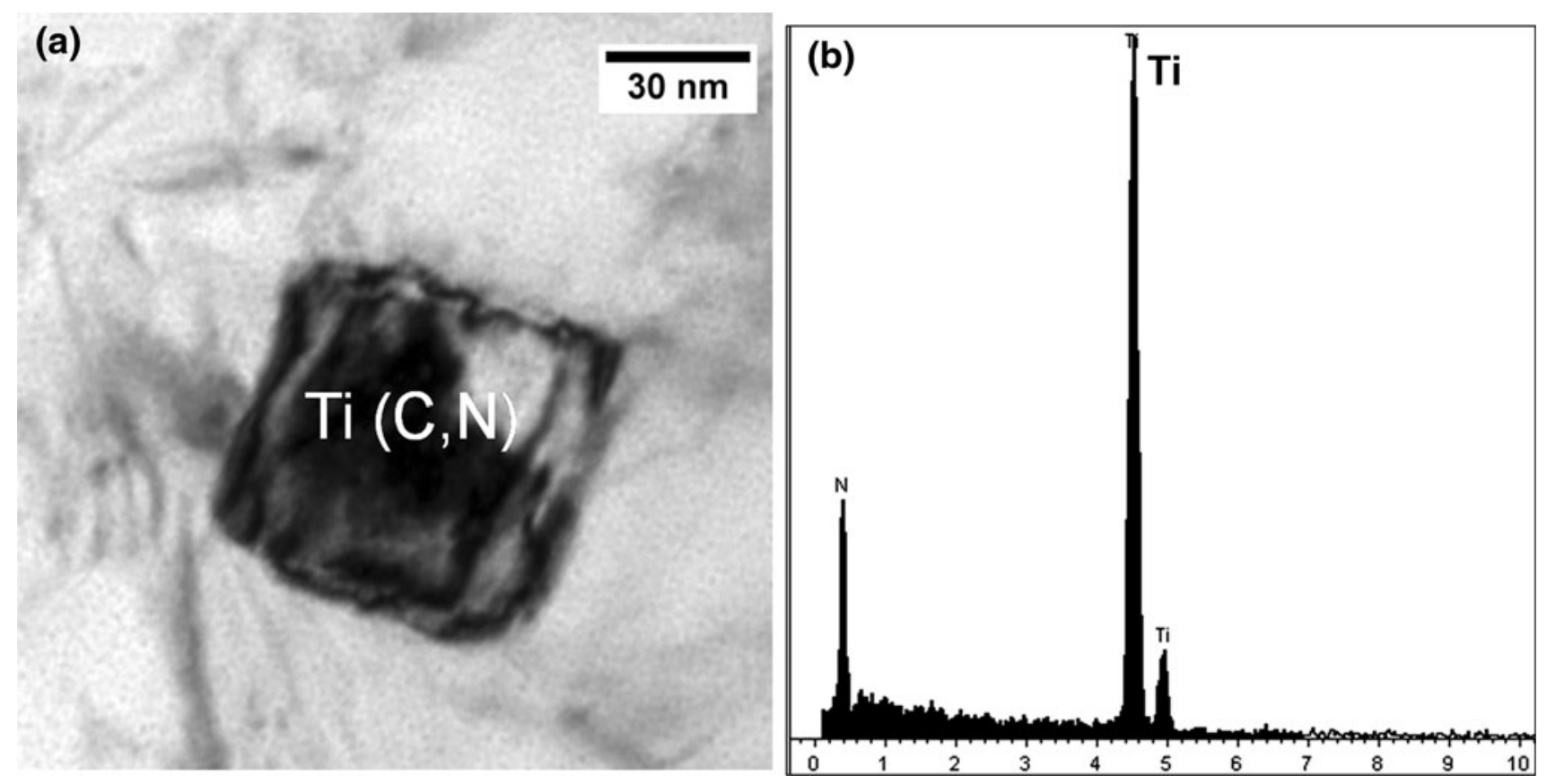

Fig. 7 Transmission electron micrograph of the solution-treated specimen at $750{ }^{\circ} \mathrm{C}$ for $0.5 \mathrm{~h}$ followed by air cooling: (a) bright-field image of cube-shaped $\operatorname{Ti}(\mathrm{C}, \mathrm{N})$ in martensite matrix. (b) EDS spectrum obtained from the $\mathrm{Ti}(\mathrm{C}, \mathrm{N})$
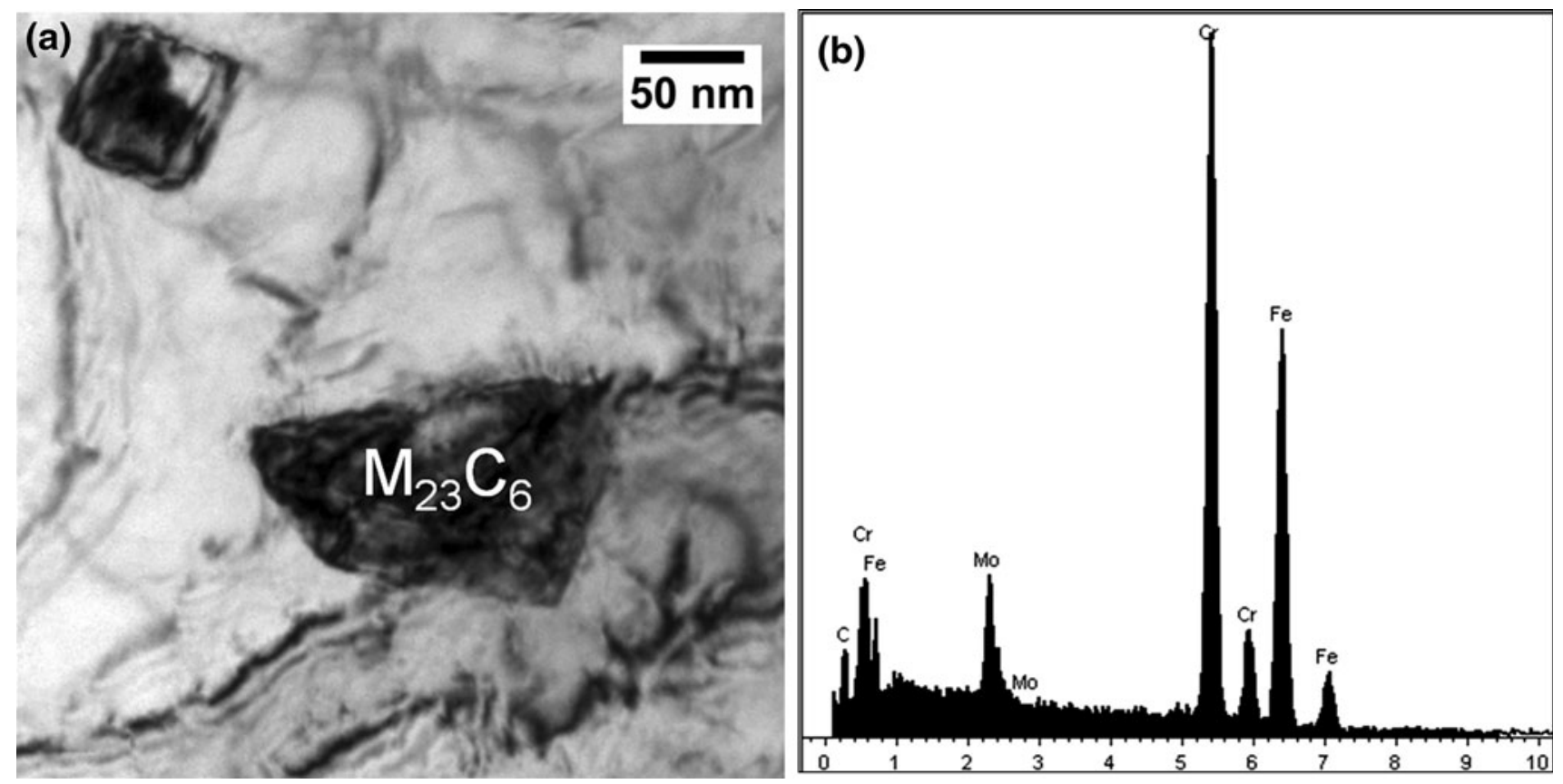

Fig. 8 Transmission electron micrograph of the solution-treated specimen at $750{ }^{\circ} \mathrm{C}$ for $0.5 \mathrm{~h}$ followed by air cooling: (a) bright-field image of $\mathrm{M}_{23} \mathrm{C}_{6}$ carbide in martensite matrix. (b) EDS spectrum obtained from the $\mathrm{M}_{23} \mathrm{C}_{6}$ carbide

precipitate. As the diffraction patterns were quite complex, orientation relationships were used for interpretation, in addition to comparison with previous studies [1-4]. The pattern was indexed on the basis of the hexagonal $\eta-\mathrm{Ni}_{3} \mathrm{Ti}$ phase $[3,4]$. The schematic of the SAD pattern with the spots indexed is shown in Fig. 9(d) and confirmed to be $\eta-\mathrm{Ni}_{3} \mathrm{Ti}$.

Compared to commercial, PH martensitic stainless steel, the present $12 \mathrm{Cr}-10 \mathrm{Ni}-0.25 \mathrm{Ti}-0.7 \mathrm{Mo}$ steel has lower precipitation hardenability which in turn results in lower 
Fig. 9 TEM image of the steel subjected to 7SCA treatment (a) bright-field image of the precipitates, (b) dark-field image of the precipitates, (c) selected area diffraction pattern, (d) schematic of SAD pattern
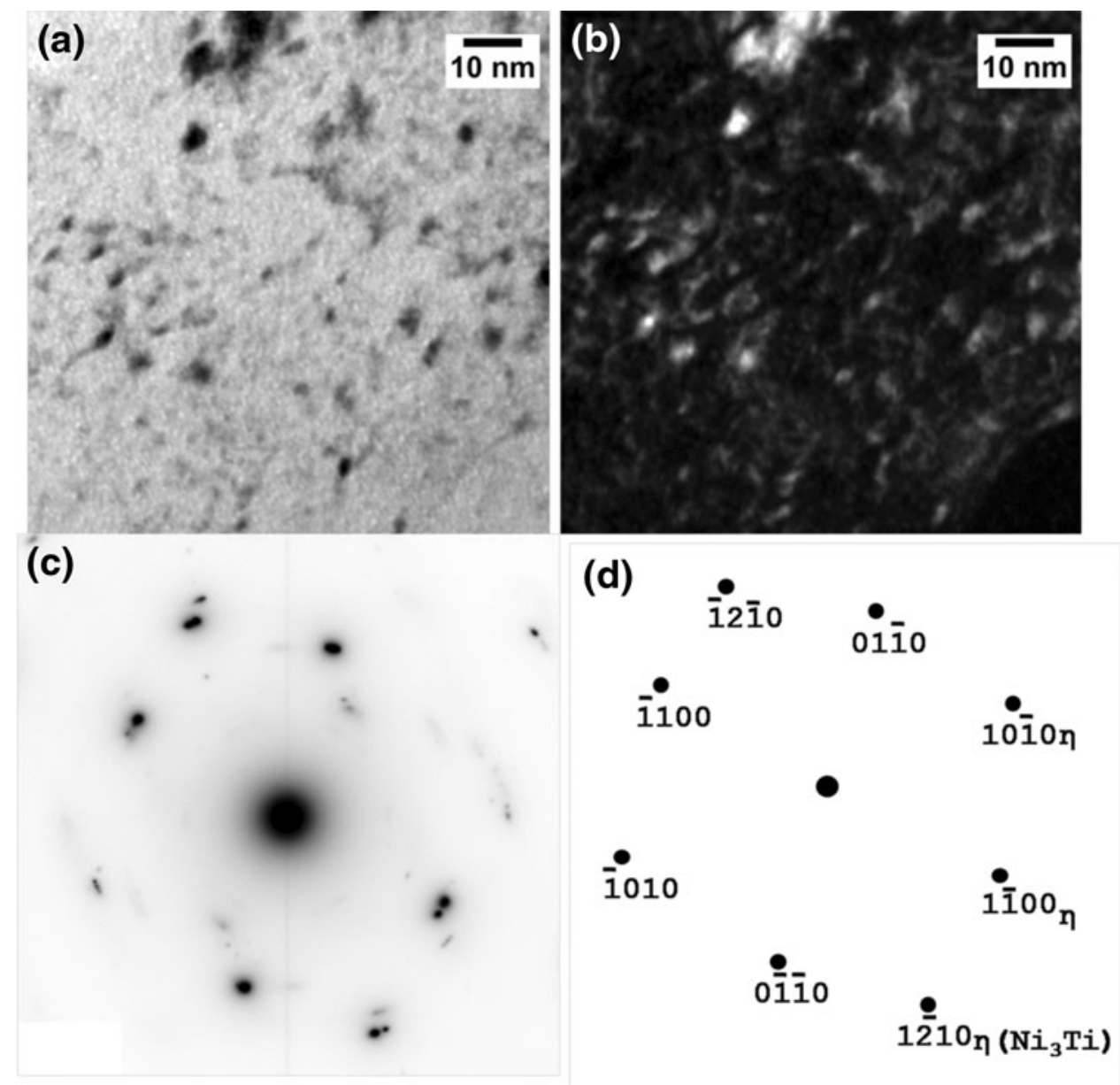

Table 3 Increase in yield strength after aging, and precipitates responsible for strengthening in $\mathrm{PH}$ martensitic stainless steel [19-23]

\begin{tabular}{|c|c|c|c|}
\hline Material & Condition & $\begin{array}{l}\% \text { Increase in yield } \\
\text { strength after } \\
\text { peak aging }\end{array}$ & Precipitates \\
\hline $\begin{array}{l}\text { Present steel } \\
12 \mathrm{Cr}-10 \mathrm{Ni}-0.7 \mathrm{Mo}- \\
0.25 \mathrm{Ti}(\mathrm{wt} \%)\end{array}$ & $\begin{array}{l}\text { Solution treatment }-1000{ }^{\circ} \mathrm{C} / \\
0.5 \mathrm{~h} / \mathrm{AC} \\
\text { Aging }-500{ }^{\circ} \mathrm{C} / 2 \mathrm{~h} / \mathrm{AC}\end{array}$ & 68.85 & $\mathrm{Ni}_{3} \mathrm{Ti}$ \\
\hline $\begin{array}{l}17-4 \mathrm{PH} \\
17 \mathrm{Cr}-4 \mathrm{Cr}-4 \mathrm{Cu}(\mathrm{wt} \%)\end{array}$ & $\begin{array}{l}\text { Solution treatment }-1038{ }^{\circ} \mathrm{C} / \\
0.5 \mathrm{~h} / \mathrm{AC} \\
\text { Aging }-496{ }^{\circ} \mathrm{C} / 4 \mathrm{~h} / \mathrm{AC}\end{array}$ & 34.5 & $\mathrm{Cu}$ \\
\hline $\begin{array}{l}\text { Custom } 455 \\
12 \mathrm{Cr}-9 \mathrm{Ni}-0.5 \mathrm{Mo}- \\
1.4 \mathrm{Ti}-2 \mathrm{Cu}(\mathrm{wt} \%)\end{array}$ & $\begin{array}{l}\text { Solution treatment }-843{ }^{\circ} \mathrm{C} / \\
0.5 \mathrm{~h} / \text { water quenching } \\
\text { Aging }-510^{\circ} \mathrm{C} / 4 \mathrm{~h} / \mathrm{AC}\end{array}$ & 95 & $\mathrm{Cu}, \mathrm{Ni}_{3} \mathrm{Ti}$ \\
\hline $\begin{array}{l}13-8 \mathrm{Mo} \mathrm{PH} \\
13 \mathrm{Cr}-8 \mathrm{Ni}-2.45 \mathrm{Mo}- \\
1.3 \mathrm{Al}(\mathrm{wt} \%)\end{array}$ & $\begin{array}{l}\text { Solution treatment }-830{ }^{\circ} \mathrm{C} / \\
40 \mathrm{~min} / \mathrm{AC} \\
\text { Aging }-482{ }^{\circ} \mathrm{C} / 4 \mathrm{~h} / \mathrm{AC}\end{array}$ & 100 & $\mathrm{NiAl}$ \\
\hline
\end{tabular}

tensile properties at room temperature. This is attributed to the fact that the present steel has a lower content of alloying elements participating in precipitation reaction. The typical alloying element content in commercial steels is typically on the order of a few weight percent: 17-4 PH (4 wt\% Cu) [5, 6], 13-8 Mo PH (1.3 wt\% Al) [19], Custom 455 (2.5 wt $\% \mathrm{Cu}, 1.4 \mathrm{wt} \% \mathrm{Ti})$ [20]; in comparison, the steel in this study contained only $0.25 \mathrm{wt} \%$ titanium. The percentage increase in YS after aging and the precipitates responsible for age hardening in $\mathrm{PH}$ steels are shown in Table 3. An increase of 34.5, 100, and 95\% in YS after aging was reported for 17-4 PH, 13-8 Mo PH, and Custom 455 , respectively. On the other hand, the present steel showed an increase of $68.85 \%$ in YS. Among these four 
steels, 13-8 Mo PH shows maximum increase in YS after aging, indicating that aluminum is a better precipitating element than $\mathrm{Ti}$ and $\mathrm{Cu}$. It is interesting to note that the present steel and Custom 455 steel are strengthened by similar type of precipitates [20]. Nevertheless, Custom 455 steel gains its additional strength first, due to copper precipitates and second, due to the higher content of Ti.

\section{Conclusions}

1. The microstructure of the solution-treated samples at 750 and $1000{ }^{\circ} \mathrm{C}$ consists of lath martensite, retained austenite, $\mathrm{Ti}(\mathrm{C}, \mathrm{N})$, and $\mathrm{M}_{23} \mathrm{C}_{6}$ carbides. Retained austenite is seen between interlath films of martensite.

2. Age hardening started at a $250{ }^{\circ} \mathrm{C}$ and peak hardening occurred in the temperature range of $400-500{ }^{\circ} \mathrm{C}$ for holding time of $1-2 \mathrm{~h}$ due to formation of fine precipitates.

3. An increase of 27 and $68 \%$ in YS was observed on aging the solution-treated and cryogenic-treated samples at 250 and $500{ }^{\circ} \mathrm{C}$, respectively.

4. The fine precipitates that form on aging are responsible for strengthening and the precipitates were identified as $\eta-\mathrm{Ni}_{3} \mathrm{Ti}$ precipitates.

5. A good combination of strength and ductility can be obtained by solution treatment at $1000{ }^{\circ} \mathrm{C}$ followed by cryogenic treatment and aging at $500{ }^{\circ} \mathrm{C}$ for $2 \mathrm{~h}$.

6. Solution treatment temperatures $\left(750\right.$ and $\left.1000^{\circ} \mathrm{C}\right)$ showed a minor effect on the mechanical properties of the studied steel.

Acknowledgments The authors would like to express their gratitude to the Director, VSSC for his kind permission to publish this study.

\section{References}

1. A. Shekhter, H.I. Aaronson, M.K. Miller, S.P. Ringer, E.V. Pereloma, Effect of aging and deformation on the microstructure and properties of $\mathrm{Fe}-\mathrm{Ni}-\mathrm{Ti}$ maraging steel. Metall. Mater. Trans. A 35(3), 973-983 (2004)

2. Y. He, K. Yang, W. Sha, Microstructure and mechanical properties of a $2000 \mathrm{MPa}$ grade Co-free maraging steel. Metall. Mater. Trans. A 36(9), 2273-2287 (2005)

3. U.K. Viswanathan, G.K. Dey, M.K. Asundi, Precipitation hardening in 350 grade maraging steel. Metall. Trans. A 24(11), 2429-2442 (1993)
4. V.K. Vasudevan, S.J. Kim, C. Marvin Wayman, Precipitation reactions and strengthening behavior in $18 \mathrm{wt}$ pct nickel maraging steels. Metall. Trans. A 21(10), 2655-2668 (1990)

5. U.K. Viswanathan, S. Banerjee, R. Krishnan, Effects of aging on the microstructure of 17-4 PH stainless steel. Mater. Sci. Eng. A 104, 181-189 (1988)

6. C.N. Hsiao, C.S. Chiou, J.R. Yang, Aging reactions in 17-4 PH stainless steel. Mater. Chem. Phys. 74, 134-142 (2002)

7. H.J. Rack, D. Kalish, The strength, fracture toughness and low cycle fatigue behaviour of 17-4 PH stainless steel. Metall. Trans. 5(7), 1595-1605 (1974)

8. F.B. Pickering, Physical Metallurgy and the Design of Steels (Applied Science Publishers, London, 1978)

9. X. Guang, X. Gan, G. Ma, F. Luo, H. Zou, The development of Ti-alloyed high strength microalloy steel. Mater. Des. 31, 2891-2896 (2010)

10. Y. Han, J. Shi, L. Xu, W.Q. Cao, H. Dong, Effects of Ti addition and reheating quenching on grain refinement and mechanical properties in low carbon medium manganese martensitic steel. Mater. Des. 34, 427-434 (2012)

11. A. Pardo, M.C. Merino, A.E. Coy, F. Viejo, M. Carboneras, R. Arrabal, Influence of $\mathrm{Ti}, \mathrm{C}$ and $\mathrm{N}$ concentration on the intergranular corrosion behaviour of AISI 216Ti and 321 stainless steels. Acta Mater. 55, 2239-2251 (2007)

12. H. Baker, H. Okamoto, ASM Handbook, vol 03: Alloy Phase Diagrams (ASM International, Materials Park, 1992)

13. C.H.I. Hong-xiao, M.A. Dang-shen, Y.O.N. Qi-long, W.U. Lizhi, Zhang. Zan-pu, W. Yong-wei, Effect of cryogenic treatment on properties of Cr8-type cold work die steel. J. Iron. Steel Res. Int. 17(6), 43-46 (2010)

14. M. El Mehtedi, P. Ricci, L. Drudi, S. El Mohtadi, M. Cabibbo, S. Spigarelli, Analysis of the effect of deep cryogenic treatment on the hardness and microstructure of X30 CrMoN 151 steel. Mater. Des. 33, 136-144 (2012)

15. M.A. Jaswin, D. Mohanlal, Effect of cryogenic treatment on the tensile behavior of EN 52 and 21-4N valve steels at room and elevated temperatures. Mater. Des. 32, 2429-2437 (2011)

16. S. Harish, A. Bensely, D. Mohanlal, A. Rajadurai, G.B. Lenkey, Microstructural study of cryogenically treated EN31 bearing steel. J. Mater. Process. Technol. 209, 3351-3357 (2009)

17. Kh. Kuo, C.L. Jia, Crystallography of M23C6 and M6C precipitated in a low alloy steel. Acta Mater. 33, 991-996 (1985)

18. D.W. Hetzner, W. Van Geertruyden, Crystallography and metallography of carbides in high alloy steels. Mater. Charact. 59, 825-841 (2008)

19. D.H. Ping, M. Ohnuma, Y. Hirakawa, Y. Kadoya, K. Hono, Microstructural evolution in $13 \mathrm{Cr}-8 \mathrm{Ni}-2.5 \mathrm{Mo}-2 \mathrm{Al}$ martensitic precipitation-hardened stainless steel. Mater. Sci. Eng. A 394(1), 285-295 (2005)

20. K. Stiller, M. Hättestrand, F. Danoix, Precipitation in $9 \mathrm{Ni}-12 \mathrm{Cr}-$ 2Cu maraging steels. Acta Mater. 46(17), 6063-6073 (1998)

21. A.K. Steel Corporation, 17-4 PH Stainless Steel Data Sheet, 17-4 PH-S-8-01-07

22. Carpenter Technology Corporation, Custom 455 Stainless Steel Technical Data Sheet (2006)

23. Y.S. Ding, L.W. Tsay, M.F. Chiang, C. Chen, Gaseous hydrogen embrittlement of PH 13-8 Mo steel. J. Nucl. Mater. 385(3), 538-544 (2009) 